\title{
Off-Site Lime Stabilisation as an Option to Treat Pit Latrine Faecal Sludge for Emergency and Existing On-Site Sanitation Systems
}

\author{
Wilson Greya, ${ }^{1}$ Bernard Thole, ${ }^{1}$ Catherine Anderson, ${ }^{2}$ Flavius Kamwani, ${ }^{1}$ \\ Jan Spit, ${ }^{2}$ and Grover Mamani ${ }^{2}$ \\ ${ }^{1}$ The Polytechnic, The University of Malawi, Private Bag 303, Blantyre, Malawi \\ ${ }^{2}$ WASTE Advisers on Urban Environment and Development, Lange Houtstraat 26, 2511 CW The Hague, Netherlands
}

Correspondence should be addressed to Bernard Thole; bthole@poly.ac.mw

Received 9 December 2015; Accepted 17 April 2016

Academic Editor: Alfieri Pollice

Copyright (C) 2016 Wilson Greya et al. This is an open access article distributed under the Creative Commons Attribution License, which permits unrestricted use, distribution, and reproduction in any medium, provided the original work is properly cited.

Off-site lime stabilisation for treating faecal sludge was assessed by undertaking small-scale $(35 \mathrm{~L})$ and large-scale $(600 \mathrm{~L})$ field trials in Blantyre, Malawi. Hydrated lime was dosed to maintain $\mathrm{pH} 10, \mathrm{pH} 10.5, \mathrm{pH} 11, \mathrm{pH} 11.5$, and $\mathrm{pH} 12$ depending on the buffer capacity of the faecal sludge in the four replica small-scale field trials. Significant reduction of $E$. coli to below the detection limit of $10^{4} \mathrm{CFU} / 100 \mathrm{~mL}$ within 1 hour of treatment was reported for $\mathrm{pH}>11$. Based on the small-scale findings, large-scale field trials were conducted and greater than $3 \log$ removal of E. coli was observed under $\mathrm{pH} 12$ conditions. Therefore, based on the study, off-site lime stabilisation by dosing lime in the range of $10-35 \% \mathrm{w} / \mathrm{w}$ (dry solid basis), depending on the buffer capacity and solids content of the sludge to maintain $\mathrm{pH}>11$, can be used to sanitise faecal sludge during emergencies, as well as for existing on-site sanitation systems.

\section{Introduction}

In emergency situations water and sanitation are critical determinants for human survival [1]. Great health risks can arise during these situations due to inadequate or unsafe excreta disposal. This is especially the case in camps and urban areas following damage to existing systems, or when parts of cities receive large numbers of displaced or homeless people, thereby putting more pressure on facilities that may already be under strain [1].

In 2015, after floods hit parts of Malawi, specifically the Lower Shire (Chikwawa and Nsanje Districts), it was estimated that more than 1,150,000 people were affected and approximately 336,000 people were displaced. More than 39 cases of cholera, including many deaths, were reported as well as many cases of diseases associated with unsafe disposal of human excreta or poor sanitation like dysentery [2]. In 2009, floods in the Lower Shire caused a cholera outbreak from which more than 1000 deaths were reported in Malawi
(Lower Shire Valley) in addition to many more deaths on the Mozambique side of the Shire River [3]. In all these scenarios, floods destroyed homes and farms and compromised access to clean water and sanitation infrastructure. In response to these natural disasters, different strategies were deployed to address immediate water and sanitation needs while establishing long-term recovery plans [2].

Among other strategies, camps were established whereby many people lived in congested places making them vulnerable to infectious diseases. Demarcation of defecation fields as well as simple pit latrines were used as on-site treatment sanitary systems to retain human excreta underground. However all the sanitation systems employed merely contained the human excreta and did not sanitise faecal sludge to prevent the spread of communicable disease.

Hydrated lime treatment has been proposed as a sanitation solution applicable to emergency situations like these due to its low cost and common availability as a building material. Small-scale and large-scale experimental trials were 
conducted to provide off-site treatment of excreta during immediate emergency phase using low-cost locally available hydrated lime. Therefore, the study intended to assess extent of faecal sludge sanitisation by lime stabilisation, its applicability and safety in real emergency situations which involve handling of large volumes of sludge.

\section{Lime Treatment Technology}

Lime is a general term used to describe several chemical compounds that share the common characteristic of being highly alkaline [4]. Lime occurs in two common forms, as calcium oxide $(\mathrm{CaO})$ or quicklime and calcium hydroxide or hydrated or slaked lime [4]. Hydrated lime, among other uses, is used for water treatment to remove hardness and for sewage treatment works. Traditionally lime has been used to reduce odour nuisance from open pits latrines and graves of domestic animals and also for wastewater treatment works to raise $\mathrm{pH}$ of stressed anaerobic digesters conditioning sludge prior to vacuum filtration. The primary objective in wastewater treatment works was to improve sludge dewaterability, but with time it was reported that odour and pathogens levels were also reduced in the process [4].

\section{Methodology}

Four replica experiments were conducted on 10 June, 15 and 26 July, and 9 August 2014 at Sochi Wastewater Treatment Plant (WWTP) and University of Malawi, The Polytechnic College, Blantyre. Each experimental set-up consisted of five batch treatment reactors using $50 \mathrm{~L}$ sealed drums and a control reactor. Each drum was filled with approximately 35 litres $(22-35 \mathrm{~kg})$ of pit latrine sludge sourced from Bangwe Market public toilets in Blantyre City using a vacuum suction pump. In order to reduce the viscosity of the faecal sludge and improve its ability to be pumped, about 50 litres of water was added into the pit during desludging to source the faecal sludge used in each experiment set. An agitator was used to mix the sludge for about five minutes to obtain homogeneity and initial samples (100-200 g) were collected by sampling from the top of the reactor and analysed for faecal coliforms, Volatile Solids (VS), Total Solids (TS), Chemical Oxygen Demand (COD), $\mathrm{pH}$, and temperature. The mass of sludge in each reactor was weighed using a bathroom scale and lime was dosed in order to achieve the desired $\mathrm{pH}$ values of each of the five treatment reactors depending on initial $\mathrm{pH}$ of sludge in each reactor. Cumulative lime dosage was derived from very small laboratory experiment conducted in beaker in previous pilot studies. In this case, lime was added to achieve $\mathrm{pH} 10, \mathrm{pH} 10.5, \mathrm{pH} 11, \mathrm{pH} 11.5$, and $\mathrm{pH}$ 12 in each of the five batch reactors. A motorised agitator was used to mix reactors uniformly for 10 minutes, and then samples (100-200 g) were taken again from each drum soon after mixing. Subsequent sampling was done after $1 \mathrm{hr}, 2 \mathrm{hrs}$, 3 hrs, 5 hrs, 24 hrs, 48 hrs, 72 hrs, 96 hrs, 120 hrs, 144 hrs, and $168 \mathrm{hrs}$. Before each sampling, motorised agitator was used to mix the reactors to obtain homogeneous mixtures.

An upscaled experiment was conducted on 25 March 2015 in two sealed 1000-litre circular water tanks, one used as the treatment reactor and the other as a control reactor. Each reactor was filled with approximately 600 litres of faecal sludge. The density of faecal sludge was measured and used to estimate the mass of sludge in each reactor. A motorised agitator was used to mix the sludge in each reactor for about five minutes and obtain homogenous mixtures. Initial samples (100-200 g) were taken and analysed for faecal coliforms, Volatile Solids (VS), Total Solids (TS), Chemical Oxygen Demand (COD), pH, and temperature. For the upscaled experiment, lime was dosed to achieve $\mathrm{pH}>11$ based on the initial $\mathrm{pH}$ and predetermined sludge buffer capacity. Triplicate samples (100-200 g) were collected from the top of each reactor at each sampling interval and analysed separately. Subsequent sampling was done after $0.5 \mathrm{hrs}, 1 \mathrm{hr}$, $2 \mathrm{hrs}, 3 \mathrm{hrs}$, and $5 \mathrm{hrs}$. Monitoring of the $\mathrm{pH}$ and temperature was also conducted after 24 and 48 hours.

\section{Experimental Methods Used}

The indicator organism E. coli was used to assess the extent of sanitation for hydrated lime treatment in both the smallscale and upscaled field trials. Additionally total coliforms were also assessed during the upscaled field trial. Both E. coli and total coliform counts were analysed using APHA 2012 Standard Method, SM-9020 pour plate (using Chromocult Coliform Agar, incubated at $37^{\circ} \mathrm{C}$ for 24 hours). Chemical Oxygen Demand (COD) was assessed using USEPA Reactor Digestion Method, Hach Lange Method 8000, and High Range (0-1500 mg COD/L) Tube Test subsequent to a 100fold dilution [5]. Total Solids and Volatile Solids were measured using Standard Method procedures SM-2540D and SM-2540E, respectively, while $\mathrm{pH}$ and temperature were measured using Standard Method, SM-4500-H [6].

\section{Results and Discussion}

5.1. Lime Dosage. Table 1 presents the average and standard deviation for lime dosages used in the four replica small-scale field trials. Lime dosages are given in kilograms as well as a percentage based on dry solids (\% kg lime/kg dry sludge) required to achieve respective $\mathrm{pH}$ conditions in each reactor.

The effective lime dosage may differ from site to site depending on environmental conditions, sludge composition, or solids content [7]. The works of Farzadkia et al. suggested that $0.265 \mathrm{~g}$ hydrated lime added per gram of sludge (equivalent to $77.9 \%$ based on dry solids) is effective to stabilise wastewater sludge $[8,9]$. In the same context, US EPA [4] recommends that actual amount of lime dosage should be a little bit higher than calculated dosage in order to maintain $\mathrm{pH}$ value for a period of at least 2 hours of treatment. Therefore, for experiments 2, 3, and 4, significant amount of lime was added in addition to minimum lime dosed according to buffer capacity of sludge in each reactor. Lime dosage to maintain desired $\mathrm{pH}$ values in each reactor ranged from $11 \pm 2.7 \%$ to $20 \pm 1.0 \%$ for reactors of $\mathrm{pH} 10-\mathrm{pH} 12$. The lime dosage required during the upscaled trial was higher at $35 \%$ based on dry solids as presented in Table 2 . In this study, approximately $25 \mathrm{~kg}$ ( $1 \mathrm{bag}$ ) of lime was used to treat approximately a half tonne of faecal sludge with an 
TABLE 1: Average lime dosage used in small-scale field trials.

\begin{tabular}{lccccc}
\hline Reactor (desired pH) & Initial pH & Sludge wt $(\mathrm{kg})$ & Initial TS $(\% \mathrm{w} / \mathrm{w})$ (wet basis) & Lime dose $(\mathrm{kg})$ & Lime dosage \% w/w (dry basis) \\
\hline Control & $6.7 \pm 0.2$ & $29.7 \pm 6.4$ & $9.3 \pm 2.4$ & $0.0 \pm 0.00$ & $0 \pm 0.0$ \\
pH 10 & $6.8 \pm 0.3$ & $33.3 \pm 6.6$ & $9.8 \pm 2.4$ & $0.3 \pm 0.07$ & $11 \pm 2.7$ \\
pH 10.5 & $6.8 \pm 0.2$ & $33.9 \pm 6.4$ & $8.2 \pm 0.7$ & $0.4 \pm 0.07$ & $14 \pm 1.1$ \\
pH 11 & $6.8 \pm 0.2$ & $31.3 \pm 7.3$ & $8.6 \pm 0.3$ & $0.4 \pm 0.10$ & $16 \pm 0.6$ \\
pH 11.5 & $6.8 \pm 0.2$ & $31.1 \pm 6.8$ & $10.0 \pm 0.3$ & $0.5 \pm 0.10$ & $15 \pm 2.4$ \\
pH 12 & $6.7 \pm 0.2$ & $33.5 \pm 7.2$ & $9.0 \pm 1.6$ & $0.6 \pm 0.16$ & $20 \pm 1.0$ \\
\hline
\end{tabular}

\pm : standard deviation across four replica experiments.

TABLE 2: Lime dosage for upscaled field trial.

\begin{tabular}{lccccr}
\hline Reactor & Initial pH & Sludge wt $(\mathrm{kg})$ & $\begin{array}{c}\text { Initial TS } \\
\text { \% w/w (wet basis) }\end{array}$ & Lime dose $(\mathrm{kg})$ & Lime dosage \% w/w (dry basis) \\
\hline Control & 6.82 & 438.80 & 2.52 & 0.00 & $0 \%$ \\
Lime system & 7.17 & 422.50 & 15.06 & 22.7 & $35 \%{ }^{* *}$ \\
\hline
\end{tabular}

${ }^{* *}$ Percentage based on weight of hydrated lime/weight of dry TS of sludge for lime treatment (w/w. TS).

TABLE 3: Average E. coli reduction for small-scale trials.

\begin{tabular}{|c|c|c|c|c|c|c|}
\hline \multirow[t]{2}{*}{ Treatment time (hrs) } & \multicolumn{6}{|c|}{$\begin{array}{c}\text { Small-scale field trial } \\
\text { Escherichia coli }(\mathrm{CFU} / 100 \mathrm{~mL})\end{array}$} \\
\hline & Control & pH 10 & pH 10.5 & pH 11 & pH 11.5 & pH 12 \\
\hline 0 & $7.7 \pm 2.3 \times 10^{7}$ & $7.2 \pm 3.3 \times 10^{7}$ & $5.9 \pm 2.7 \times 10^{7}$ & $5.7 \pm 1.2 \times 10^{7}$ & $7.8 \pm 0.6 \times 10^{7}$ & $7.2 \pm 0.3 \times 10^{7}$ \\
\hline 0.1 & Not tested & $4.9 \pm 0.5 \times 10^{6}$ & $4.3 \pm 2.8 \times 10^{7}$ & $1.9 \pm 1.2 \times 10^{6}$ & Not detected ${ }^{*}$ & Not detected* \\
\hline 1 & Not tested & $2.2 \pm 0.8 \times 10^{6}$ & $4.1 \pm 0.6 \times 10^{6}$ & Not detected ${ }^{*}$ & Not detected ${ }^{*}$ & Not detected ${ }^{*}$ \\
\hline 2 & Not tested & $1.9 \pm 0.3 \times 10^{6}$ & $1.4 \pm 0.6 \times 10^{6}$ & Not detected ${ }^{*}$ & Not detected ${ }^{*}$ & Not detected ${ }^{*}$ \\
\hline 5 & Not tested & $2.6 \pm 0.3 \times 10^{5}$ & Not detected ${ }^{*}$ & Not detected ${ }^{*}$ & Not detected ${ }^{*}$ & Not detected ${ }^{*}$ \\
\hline 24 & $4.7 \pm 2.9 \times 10^{7}$ & $1.6 \pm 1.1 \times 10^{5}$ & Not detected ${ }^{*}$ & Not detected ${ }^{*}$ & Not detected ${ }^{*}$ & Not detected* \\
\hline 48 & $8.2 \pm 4.5 \times 10^{7}$ & Detected $^{* *}$ & Detected $^{* *}$ & Not detected ${ }^{*}$ & Not detected ${ }^{*}$ & Not detected ${ }^{*}$ \\
\hline 72 & $7.1 \pm 3.2 \times 10^{7}$ & Detected $^{* *}$ & Detected $^{* *}$ & Not detected* & Not detected ${ }^{*}$ & Not detected* \\
\hline 96 & $6.0 \pm 2.6 \times 10^{7}$ & Detected $^{* *}$ & Detected $^{* *}$ & Not detected ${ }^{*}$ & Not detected ${ }^{*}$ & Not detected ${ }^{*}$ \\
\hline 120 & $6.1 \pm 5.1 \times 10^{7}$ & Detected $^{* *}$ & Detected $^{* *}$ & Not detected ${ }^{*}$ & Not detected ${ }^{*}$ & Not detected ${ }^{*}$ \\
\hline 144 & $4.7 \pm 2.9 \times 10^{7}$ & Detected $^{* *}$ & Detected $^{* *}$ & Not detected ${ }^{*}$ & Not detected ${ }^{*}$ & Not detected* \\
\hline 169 & $4.0 \pm 0.3 \times 10^{7}$ & Detected $^{* *}$ & Detected $^{* *}$ & Not detected ${ }^{*}$ & Not detected ${ }^{*}$ & Not detected ${ }^{*}$ \\
\hline
\end{tabular}

Not detected* : detection limit $10^{4} \mathrm{CFU} / 100 \mathrm{~mL}$.

Detected $^{* *}$ : detected but below viable range limit.

approximated cost of MWK 10,000 (\$20.00 USD) based on Malawian local currency.

5.2. Pathogen Reduction. The indicator organism used to analyse pathogens reduction in the small-scale field trials was Escherichia coli. Figures 1(a)-1(d) illustrate the reduction in $E$. coli count during the four replica small-scale field trials. Table 3 summarises average E. coli reduction of smallscale trials observed over the period of 168 hours. Generally, significant reduction of $E$. coli was noted in reactors of $\mathrm{pH}$ 10.5, $\mathrm{pH} 11, \mathrm{pH} 11.5$, and $\mathrm{pH} 12$. Reduction of E. coli was also observed in reactor of $\mathrm{pH} 10$. However, resistance and regrowth of pathogens were noted in reactors of $\mathrm{pH} 10$ and pH 10.5 as illustrated in Figure 1.

The results of the upscaled hydrated lime treatment experiment indicated a reduction in Escherichia coli, total coliform, and other Enterobacteriaceae soon after mixing and after 1 hour of treatment time the pathogen indicators were below the detectable range $(1000 \mathrm{CFU} / 100 \mathrm{~mL})$ as illustrated in Figures 2(a), 2(b), and 2(c). These results correlate with those of the $\mathrm{pH}>11$ reactors in the small-scale field trials. Table 4 summarises the pathogen reduction recorded during the upscaled experiment.

Generally, addition of lime to faecal sludge releases ammonia which assists in the destruction of pathogens specifically coliforms $[10,11]$ as cited by Spit et al. [12]. The containment of ammonia in the reactor acts as a biocide that further kills pathogens [13]. Pathogen reduction for lime treatment is achieved by the high $\mathrm{pH}$ levels and the ammonia concentration induced through the addition of lime $[14,15]$. Thus, the effectiveness of lime stabilisation is based on the sanitising effect of increased $\mathrm{pH}$ in combination with cell 


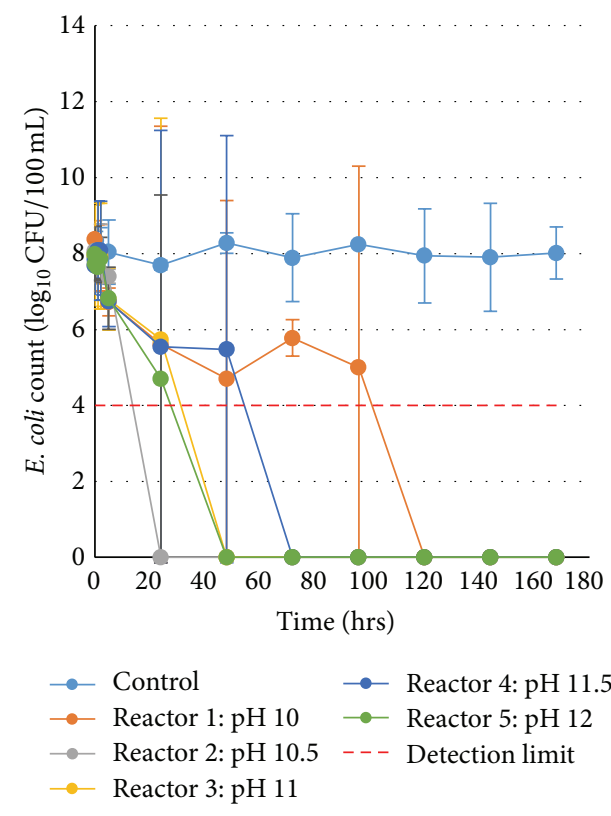

(a) Experiment 1

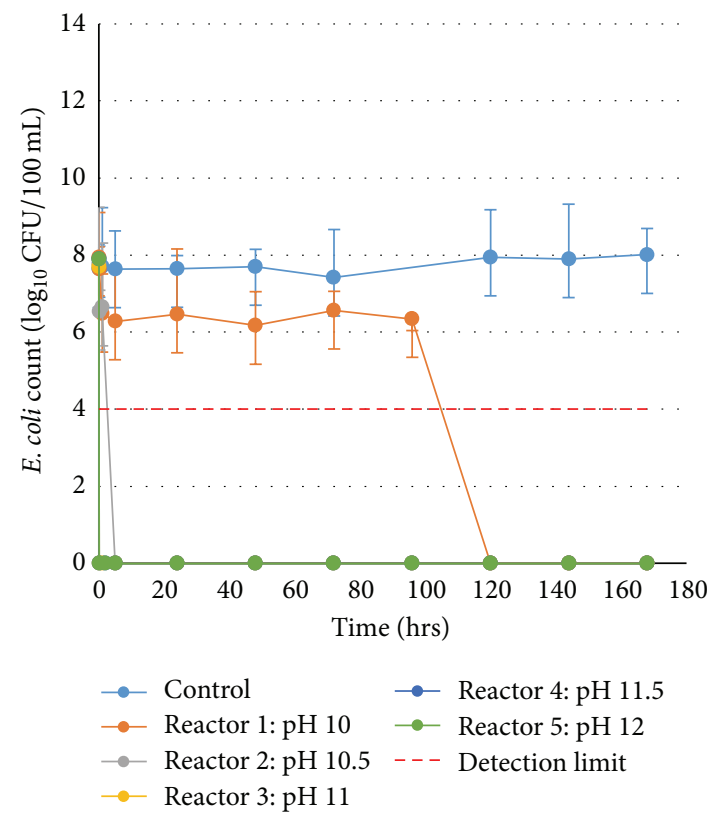

(c) Experiment 3

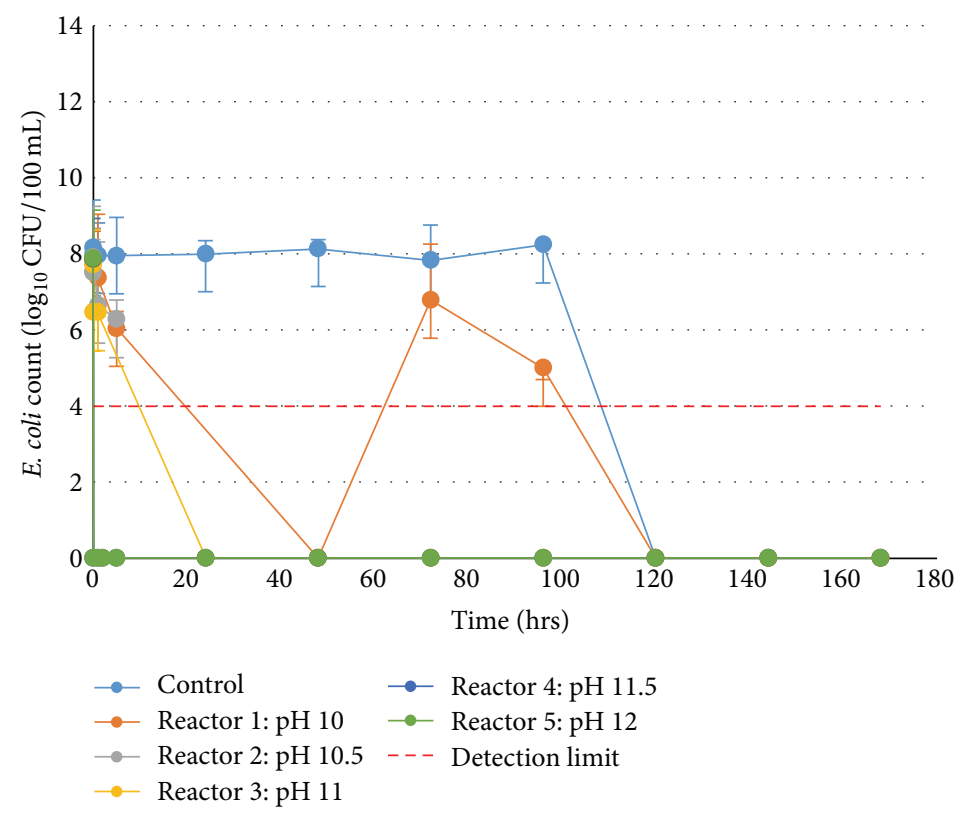

(b) Experiment 2

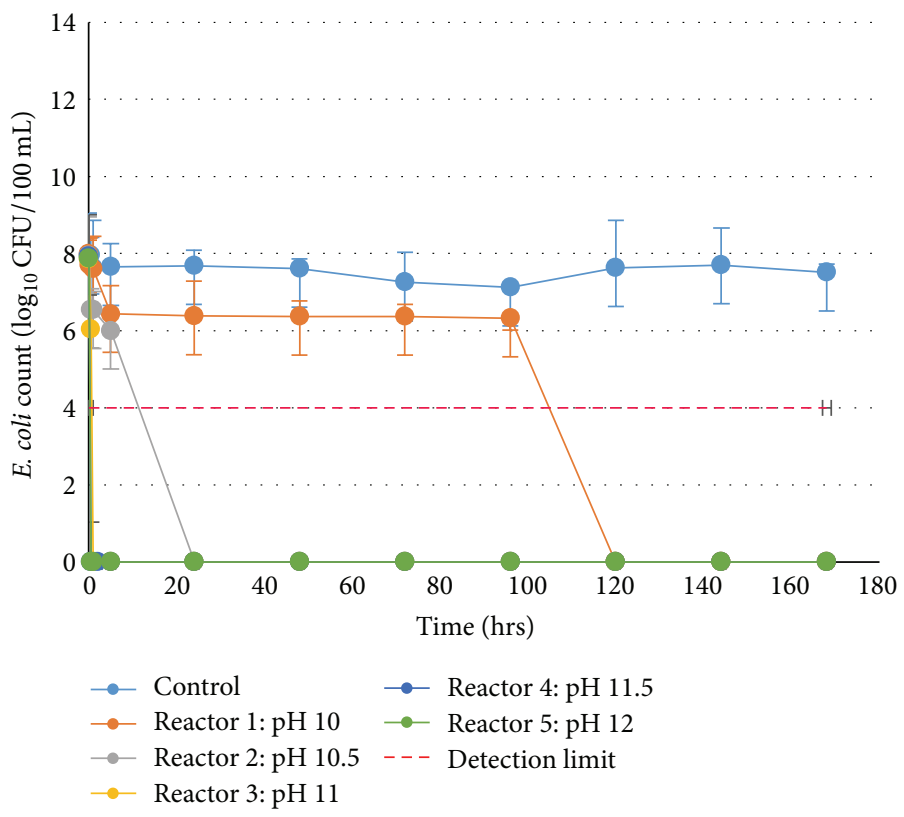

(d) Experiment 4

FIGURE 1: Escherichia coli reduction during small-scale trial.

alkalisation by uncharged ammonia $[16,17]$. Previous studies also describe the effectiveness of lime in reducing microbiological hazards in wastewater [18]. In this study, reactors dosed with lime to achieve high $\mathrm{pH}$ values reported a significant reduction of pathogens.

5.3. pH and Temperature Monitoring. US EPA $[4,19]$ outlines that for effective lime stabilisation $\mathrm{pH}$ has to be maintained above 12 for at least 2 hours and subsequent 22 hours. At $\mathrm{pH}$ level greater than 12, the cell membranes of harmful pathogens are destroyed [14]. The high $\mathrm{pH}$ also provides a vector attraction barrier, preventing flies and other insects from infesting the treated biological waste. Because lime has low solubility in water, lime molecules persist in biosolids. This helps to maintain the $\mathrm{pH}$ above 12 and prevent regrowth of pathogen [14]. In both small-scale and upscaled experiments (refer to Figure 3), this standard guideline was met. However, for the upscaled experiment, treated sludge was not stored long enough (beyond 24 hours) to monitor $\mathrm{pH}$ changes and regrowth of pathogen unlike in small scale where treated sludge was stored for a week. Regrowth of faecal coliforms was reported after 3 days of treatment in reactors 


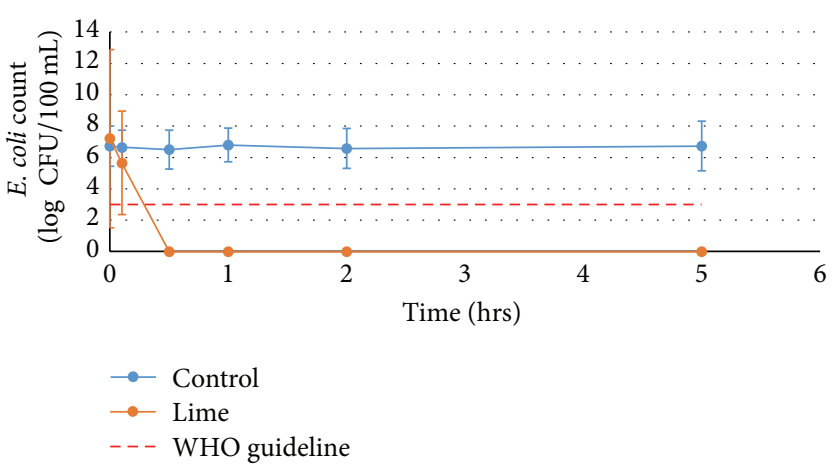

(a) Escherichia coli reduction

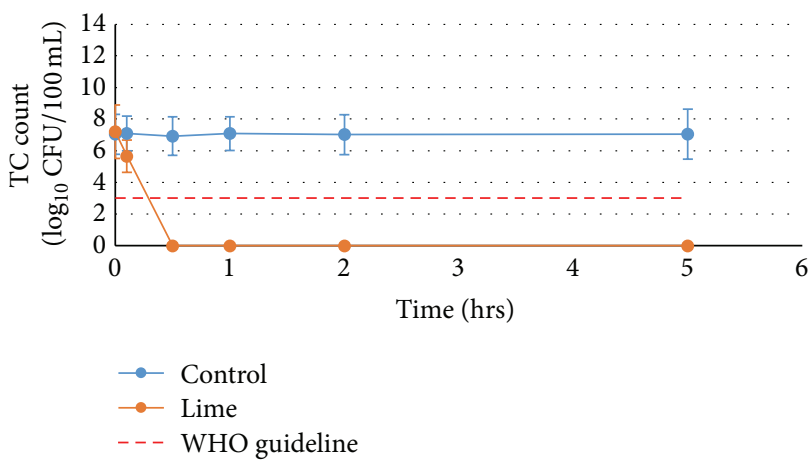

(b) Total coliform reduction

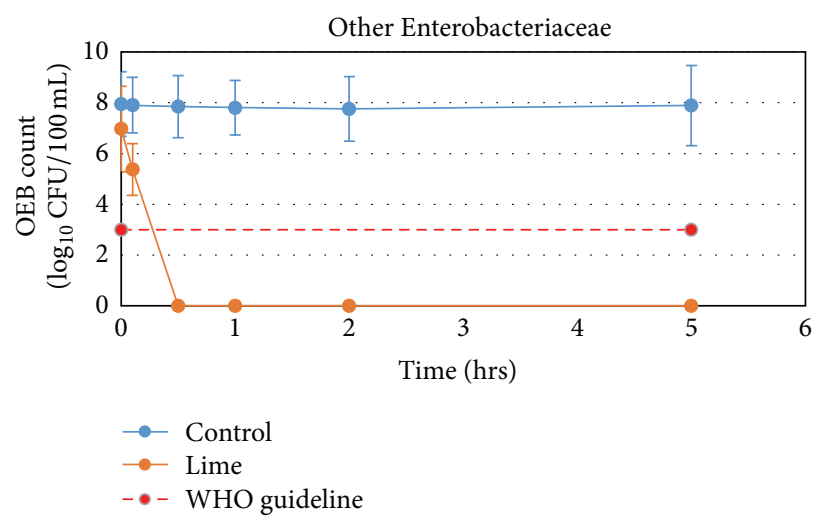

(c) Other Enterobacteriaceae reduction

Figure 2: Pathogen reduction during upscaled trial.

TABLE 4: Average reduction of E. coli and total coliforms for upscaled trial.

\begin{tabular}{|c|c|c|c|c|}
\hline \multicolumn{5}{|c|}{ Upscaled lime treatment } \\
\hline \multirow{2}{*}{ Time (hrs) } & \multicolumn{2}{|c|}{ Escherichia coli } & \multicolumn{2}{|c|}{ Total coliforms } \\
\hline & Control & Lime reactor $(\mathrm{pH} 12)$ & Control & Lime reactor $(\mathrm{pH} 12)$ \\
\hline 0 & $5.2 \pm 1.2 \times 10^{6}$ & $8.0 \pm 0.3 \times 10^{6}$ & $1.1 \pm 0.1 \times 10^{7}$ & $1.6 \pm 0.07 \times 10^{7}$ \\
\hline 0.1 & Not tested & $2.3 \pm 0.3 \times 10^{5}$ & Not tested & $4.5 \pm 1.1 \times 10^{5}$ \\
\hline 1 & Not tested & Not detected ${ }^{*}$ & Not tested & Not detected ${ }^{*}$ \\
\hline 2 & Not tested & Not detected* & Not tested & Not detected* \\
\hline 3 & Not tested & Not detected ${ }^{*}$ & Not tested & Not detected ${ }^{*}$ \\
\hline 5 & Not tested & Not detected ${ }^{*}$ & Not tested & Not detected ${ }^{*}$ \\
\hline 24 & $4.5 \pm 1.8 \times 10^{6}$ & Not tested & $1.1 \pm 0.1 \times 10^{7}$ & Not tested \\
\hline
\end{tabular}

Not detected* : detection limit $10^{3} \mathrm{CFU} / 100 \mathrm{~mL}$.

below pH 11 for small-scale lime experiments conducted as illustrated in Figure 1. This was due to drop of $\mathrm{pH}$ in subsequent hours of treatment after lime dosage and mixing. A potential reason for the drop in $\mathrm{pH}$ over time could be due to shifts in bicarbonate equilibrium. At higher $\mathrm{pH}$ conditions dissolved carbon dioxide is converted to bicarbonate and subsequently carbonate releasing protons which would assist in reducing the $\mathrm{pH}$. Additionally chemical hydrolysis of fats, carbohydrates, and proteins occurs under alkaline conditions; therefore, lactic acid, volatile fatty acids, and other acidic degradation products would also assist the reduction in $\mathrm{pH}$ throughout the treatment period [11]. It should also be noted that the experiments were conducted in ambient conditions and hence subject to daily fluctuations in temperature as detailed in Figure 3.

5.4. Total Solids and Volatile Solids. Total Solids (TS) and Volatile Solids (VS) of faecal sludge vary depending on the sludge source, desludging technique, and other environmental factors [20]. In this study, the initial TS varied on average $3 \%(9.3-12.3 \%)$ between reactors filled with the same sludge sourced from the same pit latrine illustrating the heterogeneity of the faecal sludge used in these experiments. The TS measurements taken initially, after 24 hours, and after 168 hours during the small-scale field trials are presented in Table 5. 


\begin{tabular}{l} 
Lime treatment $\mathrm{pH}$ monitoring \\
\hline
\end{tabular}

FiguRE 3: $\mathrm{pH}$ and temperature for lime reactor observed over 24 hours of treatment.

TABLE 5: Total Solids, Volatile Solids, and volatile reduction during small-scale trials.

\begin{tabular}{|c|c|c|c|c|c|c|c|c|}
\hline \multirow{2}{*}{ Reactor } & \multicolumn{3}{|c|}{ Total Solids (TS) (\% wt wet basis) } & \multicolumn{3}{|c|}{ Volatile Solids (VS) (\% wt dry basis) } & \multicolumn{2}{|c|}{ VS reduced } \\
\hline & Initial (\%) & 24 hrs (\%) & Final (168) (\%) & Initial (\%) & $24 \mathrm{hrs}(\%)$ & Final (\%) & $24 \mathrm{hrs}(\%)$ & $168 \mathrm{hrs}(\%)$ \\
\hline Control & $12.33 \pm 5.42$ & $12.53 \pm 3.5$ & $11.77 \pm 3.34$ & $71.82 \pm 4.26$ & $69.8 \pm 7.37$ & $69.23 \pm 7.37$ & $9 \%$ & $12 \%$ \\
\hline pH 10 & $9.66 \pm 24.6$ & $11.51 \pm 2.69$ & $11.03 \pm 2.79$ & $61.79 \pm 11.1$ & $60.3 \pm 9.61$ & $60.91 \pm 9.61$ & $6 \%$ & $4 \%$ \\
\hline pH 10.5 & $9.63 \pm 33.1$ & $9.96 \pm 5.34$ & $13.05 \pm 3.65$ & $69.41 \pm 7.46$ & $56.66 \pm 9.1$ & $54.52 \pm 9.05$ & $42 \%$ & $47 \%$ \\
\hline pH 11 & $12.47 \pm 29.9$ & $11 \pm 2.62$ & $11.32 \pm 2.35$ & $76.66 \pm 4.27$ & $48.28 \pm 9.2$ & $43.73 \pm 9.21$ & $72 \%$ & $76 \%$ \\
\hline $\mathrm{pH} 11.5$ & $11.21 \pm 1.57$ & $11.14 \pm 0.7$ & $11.02 \pm 1.15$ & $73.05 \pm 2.42$ & $45.77 \pm 3.1$ & $45.81 \pm 3.13$ & $69 \%$ & $69 \%$ \\
\hline $\mathrm{pH} 12$ & $11.47 \pm 4.95$ & $11.57 \pm 5.72$ & $10.49 \pm 0.75$ & $75.62 \pm 3.84$ & $47.85 \pm 8.6$ & $45.49 \pm 8.65$ & $70 \%$ & $73 \%$ \\
\hline
\end{tabular}

\pm : standard deviation across all four small-scale experiments.

Due to the heterogeneity and complexity of faecal sludge composition, no clear correlation between $\mathrm{pH}$ on TS content could be observed over the four replica experiments (Table 5). It is known that alkaline conditions affect many physiochemical as well as biochemical equilibriums. The bicarbonate equilibrium is one such chemical equilibrium affected by $\mathrm{pH}$ and alkaline conditions are said to promote carbonate precipitation, which, in addition to the added lime, would increase the TS content of the sludge as noted for $\mathrm{pH} 10$ and 10.5 conditions $[8,9]$. However, for $\mathrm{pH}>11$, a decrease in total solids was observed. Potentially, this reduction in TS could be due to highly alkaline conditions promoting organic degradation processes such as saponification and alkaline hydrolysis, the loss of nitrogen in the form of ammonia gas, or alkaline dissolution of compounds (e.g., aluminium) [11].

Similarly, average VS varied from $62 \%$ to $77 \%$ w/w dry basis for untreated sludge and from $43 \%$ to $60 \% \mathrm{w} / \mathrm{w}$ dry basis for treated sludge across reactors of $\mathrm{pH} 10, \mathrm{pH} 10.5$, $\mathrm{pH} 11, \mathrm{pH} 11.5$, and $\mathrm{pH} 12$, respectively. Vector attraction is reduced if the fraction of volatile solids of influent sludge is reduced by at least $38 \%$ during the treatment of the sludge. Hence, treated sludge can be reused if $>38 \%$ VS reduction is achieved during treatment [19]. Volatile solids reduction was calculated according to

$$
\text { VS Reduction }=\frac{V_{i}-v_{o}}{V_{i}-\left(v_{i} \times v_{o}\right)} \times 100 \%,
$$

where $V_{i}=$ Volatile Solids in untreated sludge and $V_{o}=$ Volatile Solids in treated sludge.

For treatment reactors with $\mathrm{pH}$ conditions $>10.5$, this standard stabilisation guideline was met within 24 hours with significant reduction in Volatile Solids observed during the small-scale trials (refer to Table 5). It can be noted that compared to TS higher reductions in VS were observed, in particular for treatment reactors with $\mathrm{pH}>11$. The higher reduction in VS with increasing alkaline conditions could be due to hydroxide-induced organic matter degradation processes such as saponification, cell lysis, and alkaline hydrolysis [11].

Similar VS reductions were observed in the upscaled experiment as presented in Table 6. Whilst the control reactor maintained a VS content of approximately 64-69\% w/w dry solids, the lime treatment reactor under $\mathrm{pH} 12$ conditions exhibited a VS reduction of approximately $41 \%$ from 80 down to $47 \% \mathrm{w} / \mathrm{w}$ dry basis within 24 hours.

Lime stabilisation is also a form of odour control with $\mathrm{pH}$ conditions above 11 inhibiting noxious odour-producing putrefactive bacteria. If $\mathrm{pH}$ drops below 11, however, biological decomposition will resume producing noxious odour. A disadvantage associated with lime stabilisation is the increase in sludge volume associated with lime addition and alkaline chemical precipitation [4].

5.5. Chemical Oxygen Demand. Lime stabilisation was noted not to reduce Chemical Oxygen Demand but rather to 
TABLE 6: Total Solids and Volatile Solids during upscaled trial.

\begin{tabular}{lcccccccc}
\hline \multirow{2}{*}{ Sample ID } & \multicolumn{2}{c}{ Initial } & \multicolumn{2}{c}{ Control } & \multicolumn{3}{c}{ Initial } & \multicolumn{2}{c}{ Lime treatment } & \multicolumn{2}{c}{ Final } \\
& TS (\%) & VS (\%) & TS & VS (\%) & TS (\%) & VS (\%) & TS (\%) & VS (\%) \\
\hline $\mathrm{S}_{\mathrm{A}}$ & $2.5 \%$ & $65.6 \%$ & $4.48 \%$ & $65.8 \%$ & $15.0 \%$ & $82.1 \%$ & $18.4 \%$ \\
$\mathrm{~S}_{\mathrm{B}}$ & $1.6 \%$ & $68.1 \%$ & $2.93 \%$ & $65.2 \%$ & $17.0 \%$ & $79.9 \%$ & $17.1 \%$ & $44.7 \%$ \\
$\mathrm{~S}_{\mathrm{C}}$ & $3.4 \%$ & $75.2 \%$ & $2.90 \%$ & $62.1 \%$ & $13.2 \%$ & $79.07 \%$ & $18.1 \%$ & $48.9 \%$ \\
Average & $2.5 \pm 0.9$ & $69.7 \pm 5.0$ & $3.4 \pm 0.9$ & $64.3 \pm 2.0$ & $15.1 \pm 1.9$ & $80.4 \pm 1.6$ & $17.9 \pm 0.7$ & $46.8 \pm 2.1$ \\
\hline
\end{tabular}

$\mathrm{S}_{\mathrm{A}}, \mathrm{S}_{\mathrm{B}}, \mathrm{S}_{\mathrm{C}}$ : Sample 1, Sample 2, and Sample 3, respectively. All samples were sampled from the top of the reactors. TS measurements are given as percentage of wet weight and VS measurements are given as percentage of dry weight.

TABLE 7: Average Chemical Oxygen Demand for small-scale trials.

\begin{tabular}{lccr}
\hline Batch ID & & Average Chemical Oxygen Demand & \\
& Initial (g COD/kg TS) & $24 \mathrm{hrs}(\mathrm{g}$ COD/kg TS) & Final (168) (g COD/kg TS) \\
\hline Control & $2810 \pm 1084$ & - & $3909 \pm 1440$ \\
pH 10 & $4841 \pm 2636$ & $4875 \pm 1559$ & $3750 \pm 1999$ \\
pH 10.5 & $5032 \pm 3206$ & $4825 \pm 3821$ & $3750 \pm 2199$ \\
pH 11 & $3293 \pm 2226$ & $3973 \pm 714$ & $4699 \pm 1962$ \\
pH 11.5 & $3575 \pm 1909$ & $3828 \pm 547$ & $4118 \pm 1724$ \\
pH 12 & $3646 \pm 1616$ & $4205 \pm 775$ & $4816 \pm 1785$ \\
\hline
\end{tabular}

\pm : standard deviation across four replica lime experiments.

TABLE 8: Chemical Oxygen Demand for upscaled experiment.

\begin{tabular}{lcccc}
\hline \multirow{2}{*}{ Sample ID } & \multicolumn{2}{c}{ Control } & \multicolumn{2}{c}{ Lime } \\
& Initial (g COD/kg TS) & Final (g COD/kg TS) & Initial (g COD $/ \mathrm{kg}$ TS) & Final (g COD/kg TS) \\
\hline $\mathrm{S}_{\mathrm{A}}$ & 11444 & 4764 & 1546 & 2234 \\
$\mathrm{~S}_{\mathrm{B}}$ & 15162 & 6889 & 1304 & 1738 \\
$\mathrm{~S}_{\mathrm{C}}$ & 6318 & 6801 & 1617 & 1532 \\
\hline Total average & $10975 \pm 4441$ & $6151 \pm 1202$ & $1489 \pm 164$ & $1835 \pm 361$ \\
\hline
\end{tabular}

$\mathrm{S}_{\mathrm{A}}, \mathrm{S}_{\mathrm{B}}, \mathrm{S}_{\mathrm{C}}$ : Sample 1, Sample 2, and Sample 3, respectively. All samples were sampled from the mouth of the reactors.

increase it as summarised in Tables 7 and 8 for small-scale and upscaled trials, respectively. In Table 7, in comparison to initial COD and 24 hours of treatment, slight increase of COD was noted after period of 168 hours of treatment. However, Analysis of Variance (ANOVA) $\propto=0.05, p$ value $=0.455$, reported that there was no significant difference of extent of stabilisation in terms of COD after the periods of 24 hours and 168 hours treatment across all five reactors of four replica experiments. Small-scale trials reported average Chemical Oxygen Demand to vary in the range of 373.3 $\pm 144.40 \mathrm{CODg} / \mathrm{L}$ to $606.0 \pm 193.74 \mathrm{CODg} / \mathrm{L}$ unlike for upscaled trial of which COD varied from $220.5 \pm 9.01$ to $355 \pm 77.95$ for untreated and treated sludge. The decreasing COD trends observed for the control reactor in the upscaled experiment (Table 8) potentially indicate biological oxidation of organic matter throughout the treatment period; however, it could also merely reflect the heterogeneity of the faecal sludge. For the lime treatment reactor in the upscaled experiment, however, the highly alkaline conditions would have inhibited any biological organic degradation and the observed increasing trend in COD could be due to the alkaline conditions chemically reducing compounds.

\section{Conclusion}

In line with other previous studies [10, 12, 21], lime stabilisation in this study was able to sanitise faecal sludge to below the detection limit of $10^{4} \mathrm{CFU} / 100 \mathrm{~mL}$ during four replica small-scale field trials. During the upscaled field trial the WHO standard guideline of $1000 \mathrm{CFU} / 100 \mathrm{~mL}$ was achieved within 1 hour at $\mathrm{pH} 12$. The effective lime dosage varied from 10 to $35 \% \mathrm{w} / \mathrm{w}$ (dry basis) depending on initial $\mathrm{pH}$, sludge alkalinity, and Total Solids (TS) content. Therefore, this study demonstrated that off-site lime stabilisation can be adopted to treat faecal sludge during acute phase of an emergency situation when immediate response is required. The study also reported a reasonable reduction in Volatile Solids content and the potential for the treated sludge to be reused in agriculture to neutralise acidic soils.

\section{Additional Points}

The term sanitisation referring to treated sludge is slightly controversial in the sense that indicators used (faecal coliforms) to determine contamination by human faecal excreta 
do not determine presence or absence of all other pathogens specifically viruses [22]. Therefore, further studies on analysis of viral pathogens are required. Biomonitoring to investigate if life can be supported is also another area which can be researched further, in case of emergency situations where treated human wastes can be dumped into fresh water bodies.

\section{Competing Interests}

The authors declare no conflict of interests.

\section{Authors' Contributions}

Wilson Greya designed and performed the field experiments, conducted all associated laboratory analyses, and drafted the paper. Flavius Kamwani assisted in conducting some laboratory analyses during field trials. Bernard Thole, Catherine Anderson, Jan Spit, and Grover Mamani conceived of the study and provided assistance during the design and execution of the field trials. Bernard Thole and Catherine Anderson also contributed significantly to editing the paper.

\section{Acknowledgments}

This study was supported by WASTE (an organisation dealing with waste management in Netherlands) in search for solutions to poor faecal sludge management during emergency situations. Special thanks are due to Catherine Anderson and Bernard Thole for their generous support in completion of upscaled field trials.

\section{References}

[1] B. Wisner and J. Adams, Environmental Health in Emergencies and Disasters: A Practical Guide, World Health Organization, Geneva, Switzerland, 2002.

[2] WaterforPeople, “The Malawi Floods," 2015, http://www.nyasatimes.com/2015/01/15/cholera-outbreak-fears-over-malawifloods/.

[3] http://www.voanews.com/content/cholera-outbreak-in-malawi-causes-concern/2661751.html.

[4] US EPA, Process Design Manual for Sludge Treatment and Disposal, Centre for Environmental Research Information Technology Transfer, Washington, DC, USA, 1979.

[5] Hach, "Hach Method 8000: USEPA Reactor Digestion Method DOC 316.53.01099," 2014, http://www.hach.com/asset-get.download.jsa?id=7639983640.

[6] American Public Health Association (APHA), Standard Methods for Examination of Water and Waste Water, American Public Health Association (APHA), Washington, DC, USA, 2012.

[7] P. Samaras, C. A. Papadimitriou, I. Haritou, and A. I. Zouboulis, "Investigation of sewage sludge stabilization potential by the addition of fly ash and lime," Journal of Hazardous Materials, vol. 154, no. 1-3, pp. 1052-1059, 2008.

[8] M. Farzadkia and E. Bazrafshan, "Lime stabilisation of waste activated sludge," Healthscope, vol. 3, no. 1, pp. 1129-1133, 2006.

[9] M. Farzadkia, "Investigation of sludge stabilization and reuse in four small treatment plants of Tehran City," Scientific Journal of
Hamadan University of Medical Sciences, vol. 9, no. 2, pp. 51-55, 2002.

[10] B. Bina, H. Movahedian, and I. Kord, "The effect of lime stabilization on the microbiological quality of sewage sludge," Iranian Journal of Environmental Health Science \& Engineering, vol. 1, no. 1, pp. 34-38, 2004.

[11] C. Williford, W. Y. Chen, N. K. Shammas, and L. K. Wang, "Lime stabilisation," in Biosolids Treatment Processes, chapter 7, pp. 207-242, Springer, 2007.

[12] J. Spit, D. Malambo, M. E. Gonzalez, H. Nobela, L. de Pooter, and K. Anderson, Emergency Sanitation: Feacal Sludge Management, WASTE, Gouda, The Netherlands, 2014.

[13] K. B. Fitzmorris, R. S. Reimers, J. A. Oleszkiewicz, and M. D. Little, "Decrease of time for pathogen inactivation in alkaline disinfection systems using pressure," Water Environment Research, vol. 79, no. 4, pp. 388-395, 2007.

[14] Schwing Bioset, Moss Kelley, 2009, http://www.mosskelley.com/ case_studies/Bioset_Process.pdf.

[15] S. Wang and T. Viraraghavan, "Wastewater sludge conditioning by ash fly," Journal of Waste Management, vol. 17, no. 1, pp. 447450, 1997.

[16] K. Emerson, R. C. Russo, R. E. Lund, and R. V. Thurston, "Aqueous ammonia equilibrium calculations: effect of $\mathrm{pH}$ and temperature," Journal of the Fisheries Research Board of Canada, vol. 32, no. 12, pp. 2379-2383, 1975.

[17] K. Warren, "Ammonia toxicity and pH," Nature, vol. 195, no. 1, pp. 47-49, 1962.

[18] B. Mignotte-Cadiergues, A. Maul, A. Huyard, S. Capizzi, and L. Schwartzbrod, "The effect of liming on the microbiological quality of urban sludge," Water Science and Technology, vol. 43, no. 12, pp. 195-200, 2001.

[19] US Environmental Protection Agency, Standards for the Use of and Disposasl of Sewege Sludge 4CR Part 503-Final Rule, Centre for Environmental Research Information Technology Transfer, Washington, Wash, USA, 1993.

[20] U. Heinss, S. A. Larmie, and M. Strauss, Characteristics of Faecal Sludges and Their Solids-Liquid Separation, EAWAG/SANDEC, Rio de Janeiro, Brazil, 1999.

[21] C. Anderson, D. H. Malambo, M. E. G. Perez et al., "Lactic acid fermentation, urea and lime addition: promising faecal sludge sanitizing methods for emergency sanitation," International Journal of Environmental Research and Public Health, vol. 12, no. 11, pp. 13871-13885, 2015.

[22] G. Berg and D. Berman, "Destruction by anaerobic mesophilic and thermophilic digestion of viruses and indicator bacteria indigenous to domestic sludges," Applied and Environmental Microbiology, vol. 39, no. 2, pp. 361-368, 1980. 

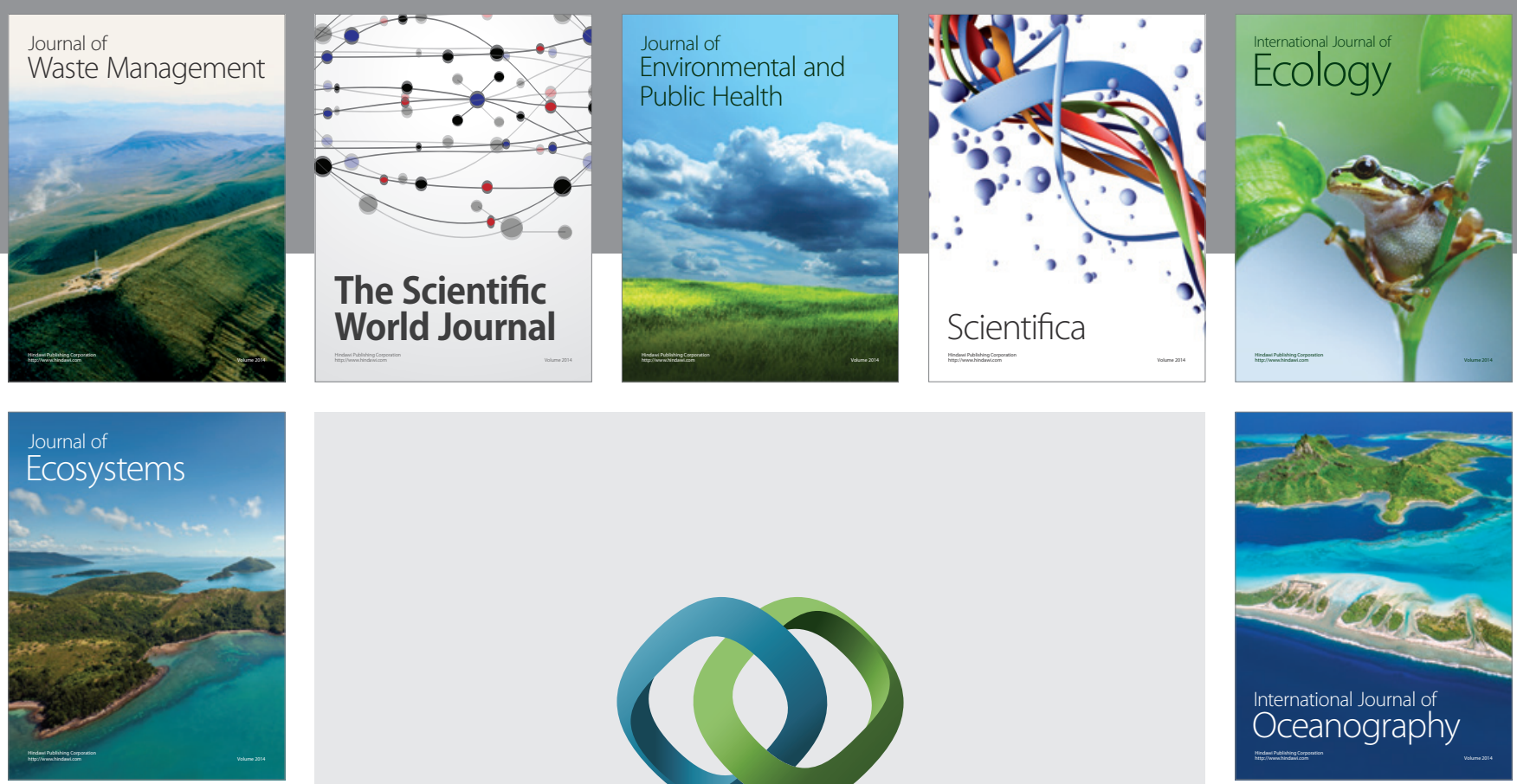

The Scientific World Journal
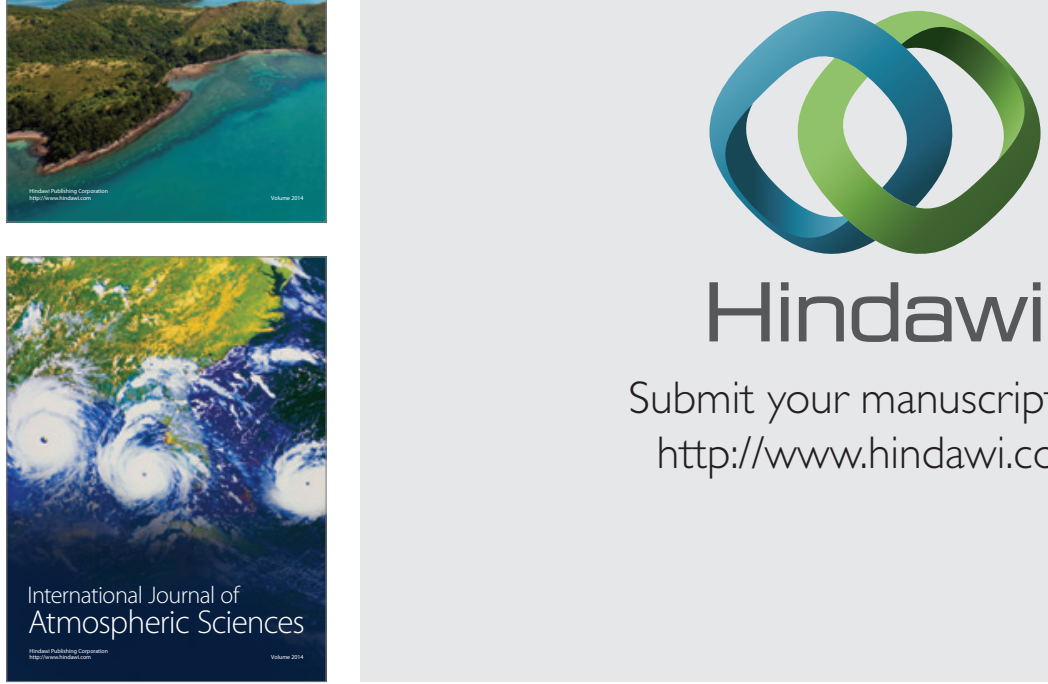

\section{Hindawi}

Submit your manuscripts at

http://www.hindawi.com
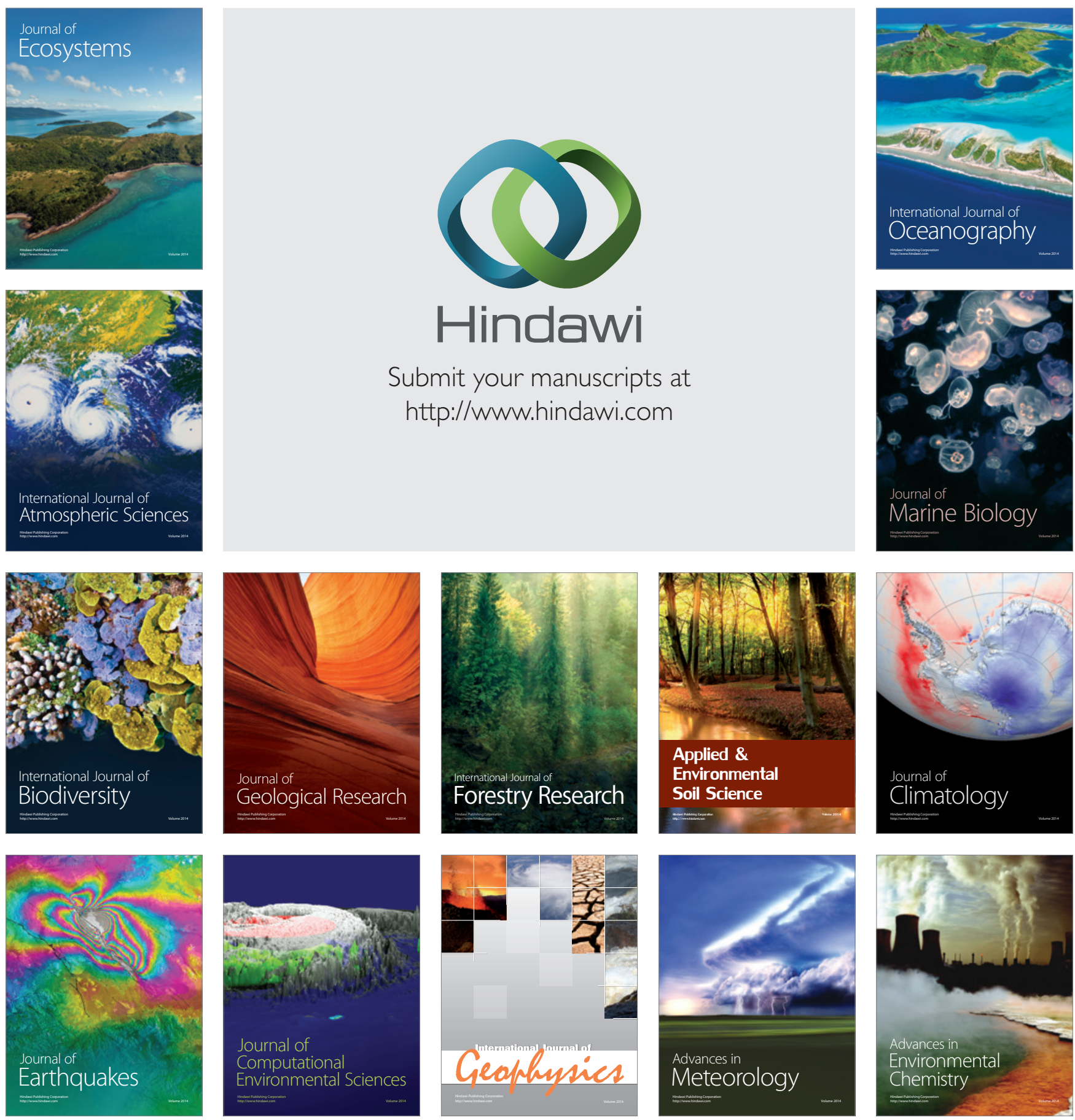